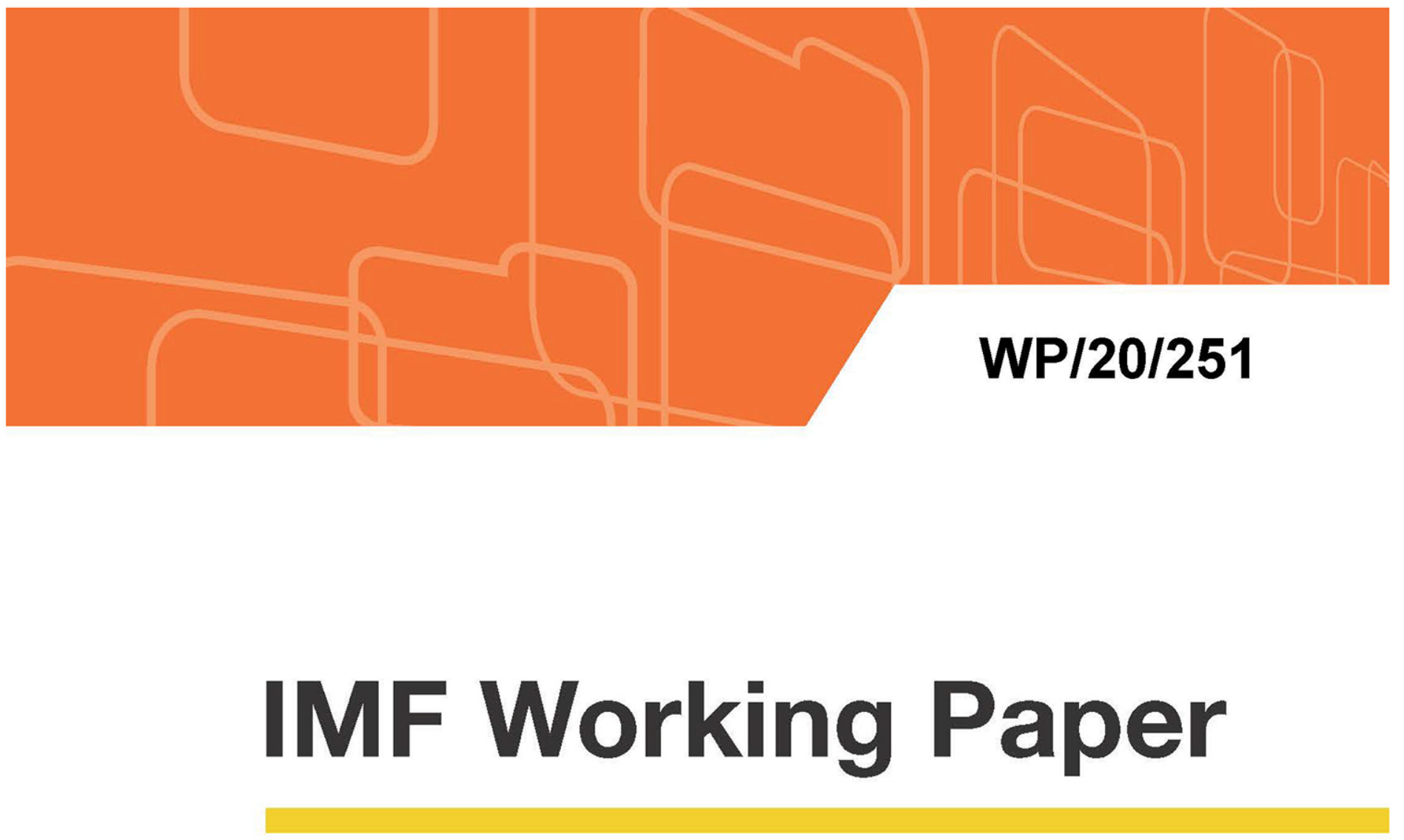

\title{
India's Inflation Process Before and After Flexible Inflation Targeting
}

by Patrick Blagrave and Weicheng Lian

IMF Working Papers describe research in progress by the author(s) and are published to elicit comments and to encourage debate. The views expressed in IMF Working Papers are those of the author(s) and do not necessarily represent the views of the IMF, its Executive Board, or IMF management.

$$
\text { I N T E R N A T I O N A L M O N E T A R Y F U N D }
$$




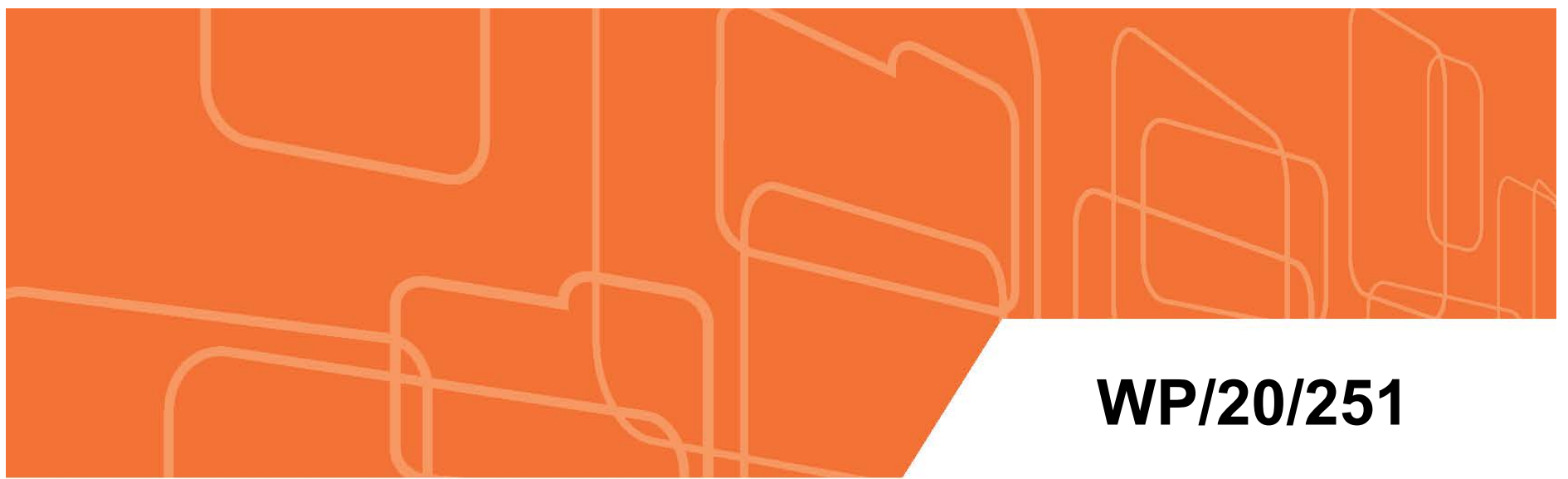

IMF Working Paper

\section{India's Inflation Process Before and After Flexible Inflation Targeting}

by Patrick Blagrave and Weicheng Lian

IMF Working Papers describe research in progress by the author(s) and are published to elicit comments and to encourage debate. The views expressed in IMF Working Papers are those of the author(s) and do not necessarily represent the views of the IMF, its Executive Board, or IMF management.

I N T E R N A T I O N A L M O N E T A R Y F U N D 


\title{
IMF Working Paper
}

Asia and Pacific

\section{India's Inflation Process Before and After Flexible Inflation Targeting Prepared by Patrick Blagrave and Weicheng Lian ${ }^{1}$}

Authorized for distribution by Ranil Salgado

November 2020

\section{IMF Working Papers describe research in progress by the author(s) and are published to elicit comments and to encourage debate. The views expressed in IMF Working Papers are those of the author(s) and do not necessarily represent the views of the IMF, its Executive Board, or IMF management.}

\begin{abstract}
We study the inflation process in India, focusing on the periods before and after the adoption of flexible inflation-forecast targeting (FIT) in India. Our analysis uses several approaches including standard Phillips curve estimation for headline and core inflation, an examination of the sensitivity of medium-term inflation expectations to inflation surprises, and the properties of convergence between headline and core inflation. Results indicate an important role for domestic factors in driving the inflation process, and there is evidence that expectations have become more anchored since 2015. This result could be attributable to FIT adoption, or to persistently low food prices which dominate the post-FIT-adoption period. The policy implications of these structural changes in the inflation process are investigated using a semi-structural model calibrated to the Indian economy.

JEL Classification Numbers: E31, E52

Keywords: Inflation targeting; Inflation; India

Author's E-Mail Address: Pblagrave@,imf.org, Wlian@,imf.org

\footnotetext{
${ }^{1}$ We are grateful to Hamid Davoodi, Thomas McGregor, Ranil Salgado, and colleagues at the Reserve Bank of India for valuable feedback, and to Nimarjit Singh for excellent research support. The opinions expressed herein are solely the responsibility of the authors and should not be interpreted as reflecting those of the IMF, its Executive Board, or IMF management.
} 


\section{Contents}

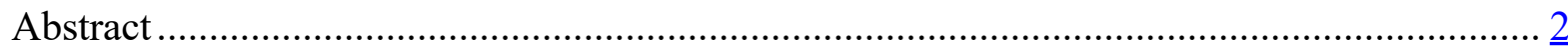

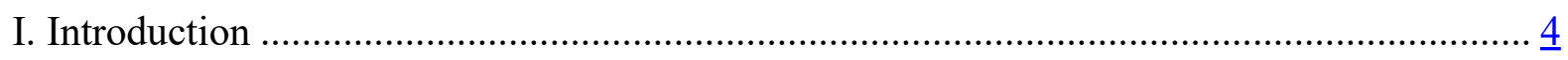

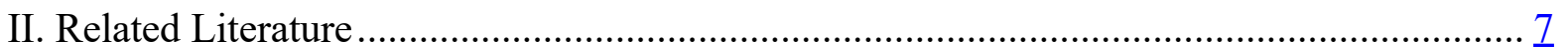

III. Empirical Analysis ..................................................................................................

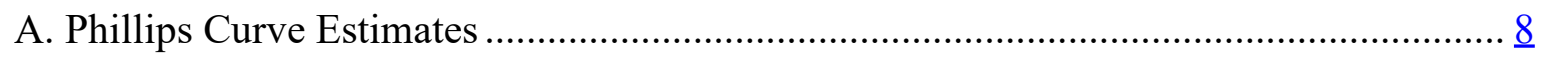

B. Changes in the Anchoring of Inflation Expectations …………………………….... 10

C. Second-Round Effects: The Role of Food Inflation.................................................... 12

IV. Policy implications: model-based simulations .......................................................... 15

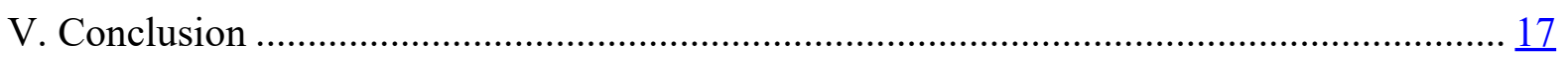

Appendix: Robustness of Results to the Structural Break Point..................................... 19

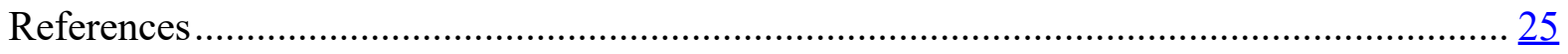




\section{INTRODUCTION}

The adoption of flexible inflation targeting (FIT) was a landmark step forward for the conduct of monetary policy in India. ${ }^{2}$ It has coincided with relatively low and more stable inflation in recent years, compared to a period of persistently high inflation previously. It also featured remarkably subdued food price inflation for an extended periodfrom late 2016 through mid-2019coinciding with a marked divergence between food and core inflation. While this apparent shift in the inflation process around 2015 has been recognized by previous studies (Dholakia and Kadiyala (2018) and Chinoy (2019)), there is currently no consensus regarding the factors which drove it. ${ }^{3}$

The experiences of other countries suggest that inflation performances tended to improve after the adoption of FIT. A simple event-study analysis shows that the transition to FIT has lowered emerging market and developing economy (EMDE) countries' positive inflation differential, vis-à-vis a set of non-FIT peer countries. This pattern indicates a role played by domestic monetary institutions in affecting inflation dynamics (see also Bems and others (2018b)).

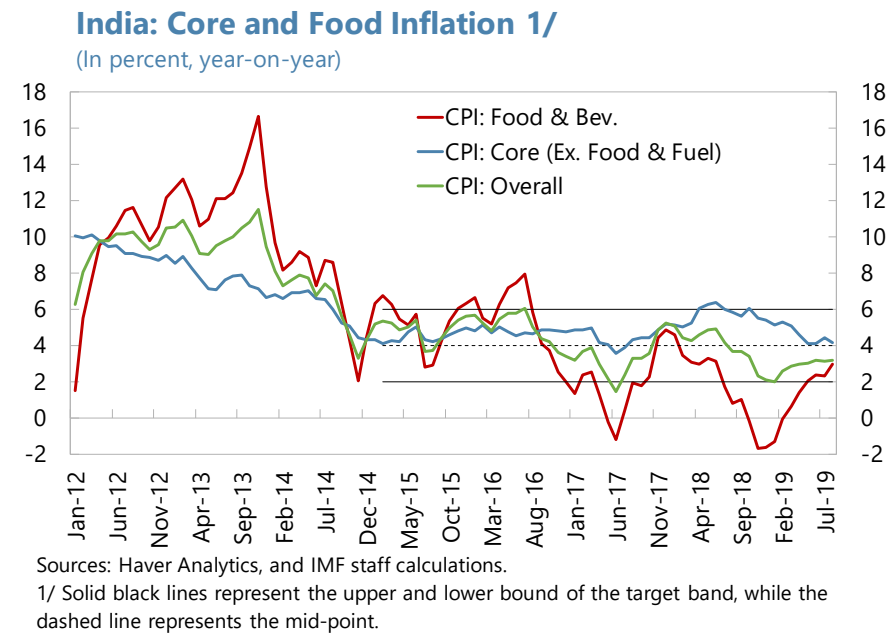

India: Core and Food Inflation 1/

percent, year-on-year) .

?

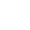


the RBI Act and constitution of a Monetary Policy Committee followed later, in June and September of 2016, respectively. ${ }^{4}$ Our analysis looks specifically at the role played by domestic factors, and whether inflation expectations have become more anchored since early 2015. We contribute to the literature that analyses the determinants of inflation in India (Anand, Ding, and Tulin (2014); Sonna and others (2014); Behera, Wahi and Kapur (2018); Pattanaik, Muduli, and Ray (2019)) — a more expansive discussion of the literature is provided in section 2 of this paper. Although these studies have looked at headline and foodprice inflation processes in India, our paper focuses more on any changes in the inflation process since the adoption of FIT.

Our analysis begins by examining headline and core inflation processes in India using standard Phillips curves (Gali and Gertler (1999)). We focus on differences between India and other emerging market and developing economies in the inflation processes. We find that the inertia of headline inflation in India between 2004Q1 and 2019Q4 was stronger than in other emerging markets examined in our study, and that the difference was entirely driven by the non-core inflation component. ${ }^{5}$

Next, we take two steps to explore whether inflation expectations have become more anchored since 2015. First, we measure the degree of anchoring of inflation expectations by looking at the sensitivity of medium-term inflation expectations to inflation surprises. This metric to measure the degree of anchoring of inflation expectations is in the same spirit of those constructed by Bems and others (2018a). We find forecasters were less likely to revise medium-term inflation expectations in the period after 2015 - the distribution of mediumterm inflation expectations revision became narrower. Meanwhile, the sensitivity of mediumterm inflation expectations to inflation surprises also declined.

We also study second-round effects of inflationary shocks through an exercise proposed by Cecchetti and Moessner (2008), which looks at the response of headline/core inflation to a gap between headline and core inflation. ${ }^{6}$ The difference relative to their approach is that we not only look at the response of headline inflation to this gap, but also its largest subcomponent, food price inflation. The results show that it is more likely for headline inflation to have converged to core inflation rather than vice versa since early 2015 , suggesting limited second-round effects.

\footnotetext{
${ }^{4}$ To alleviate the concern that expecting a change in the monetary policy regime can affect the inflation process, we also conduct a robustness test setting the FIT adoption date as the beginning of 2014. The results are broadly the same.

${ }^{5}$ We study 33 emerging market economies for which we can construct import price inflation at the quarterly frequency: Albania, Bolivia, Botswana, Brazil, Bulgaria, Chile, China, Colombia, Croatia, Dominican Republic, Ecuador, El Salvador, Honduras, Hungary, India, Indonesia, Malaysia, Mexico, Mongolia, Nicaragua, Pakistan, Panama, Paraguay, Peru, Philippines, Poland, Romania, Russia, Rwanda, Serbia, South Africa, Thailand, and Turkey.

${ }^{6}$ Anand, Ding, and Tulin (2014) uses the approach in India's context.
} 
On balance, our empirical results suggest more anchored inflation expectations and a shift in the inflation process, post-FIT adoption. One vital caveat of interpreting these empirical patterns is that persistent food-supply shocks may also stand behind these structural changes - these shocks have been large and negative in recent years, causing food prices to remain low. ${ }^{7}$ As such, the patterns we obtain do not necessarily imply a permanent structural change in the relationship between core and headline inflation.

Furthermore, our findings suggest that domestic factors rather than global forces stand behind changes in the inflation process, which is supported by three findings:

1. The import price pass-through is positive and significant for core inflation and insignificant for headline inflation. Given a large share of food in the consumption basket, this pattern implies segmentation between domestic and international food markets.

2. Food price inflation played a significant role in the pre/post-2015 change of the convergence properties between headline and core inflation.

3. It is the domestic rather than international component of food price inflation that became more likely to converge to core inflation after 2015.

Finally, to assess the policy implications of our empirical findings, we conduct simulations using a variant of the RBI's benchmark macroeconomic model (Benes and others (2017)). Simulations show how greater anchoring of inflation expectations and lower second-round effects of food/fuel shocks improve the tradeoff between stabilizing inflation and closing the output gap. The optimal interest-rate response to inflation shocks is more limited when expectations are better anchored, implying that inflation can be returned to target at a smaller economic cost in terms of foregone economic output.

We must state at the outset that our findings do not definitively link the observed changes in the inflation process in India to FIT adoption. There are a number of obstacles which prevent us from doing so, including: (i) the endogenous nature of the choice of monetary policy regime, (ii) the endogenous timing decision of the adoption of FIT, (iii) the separation of domestic from global factors that may be jointly driving inflation dynamics, macroeconomic outcomes, and policy responses in India, and (iv) the coincidence of successive negative food-price shocks. For these reasons, our results should be taken as suggestive, but are certainly consistent with the conclusion that inflation outcomes in India have improved under inflation targeting.

The remainder of the paper is organized as follows. Section 2 provides a brief overview of the related literature. Empirical analysis is presented in section 3, which include Phillips curve estimates, an examination of the anchoring of inflation expectations, and regressions

\footnotetext{
${ }^{7}$ In this paper, we are agnostic regarding the drivers of these persistent food-price shocks - they could equally reflect stronger harvests, a shift in government policies towards agriculture such as the introduction of the National Food Security Act in 2013, other factors, or a combination of all of these.
} 
analyzing the convergence between headline and core inflation. Section 4 presents the results of our model simulations, and section 5 concludes.

\section{RELATED LiterATURE}

Previous studies of India's inflation process highlight a high degree of inflation persistence, its sensitivity to food/fuel shocks (Behera, Wahi and Kapur (2018); Pattanaik, Muduli and Ray (2019)), and a significant role of exchange-rate passthrough (Patra, Khundrakpam, and Joice (2018)). Sonna and others (2014) examine the determinants of food inflation in India, linking this primarily to the evolution of rural real wages. Recent cross-country analyses suggest a prominent role for domestic factors in India's inflation process. For example, Bems and others (2018b) and IMF (2018) show a limited role for external price pressures in shaping India's inflation and that India stands out among emerging markets as having a greater share of inflation variation explained by domestic as compared to global factors. Finally, looking specifically at the relationship between core and headline inflation, Anand, Ding, and Tulin (2014) show that for the sample period 1997-2013, headline inflation did not revert to core inflation (either second-round effects are significant, or non-core inflation shocks are persistent), but that core did revert rapidly to headline inflation (evidence in favor of second-round effects). Our study complements the existing literature by providing a more recent assessment of the inflation process in India and highlights the role of domestic factors in shifting this process.

There is also a large strand of literature that examines the role played by inflation targeting in driving inflation outcomes. Goncalves and Salles (2008) and Lin and Ye (2009) provide evidence that inflation targeting (IT) has been beneficial in emerging market economies (EMs). The former finds that those who adopted an IT regime experienced lower inflation and smoother growth. The latter shows that the regime reduces the level and variability of inflation, on average, among a set of $13 \mathrm{EMs}$, but that the experience among countries is quite heterogeneous, depending on country characteristics. De Mendonca and de Guimaraes e Souza (2012) corroborate the notion that IT adoption leads to lower level and volatility of inflation, underscoring that this holds only in their developing country sample-for advanced economies, it is not clear that IT adoption carried substantial benefits, vis-à-vis inflation lowering/stabilization. Samarina, Terpstra, and De Haan (2013) also show that IT adopters in emerging and developing economies benefitted substantially (in terms of reducing inflation), and in a specific application for the Asia-Pacific region, Gerlach and Tillmann (2012) find that inflation persistence declines following the adoption of IT. Finally, Eichengreen, Gupta, and Choudhary (2020) provide an assessment of the IT regime in India, showing that the RBI is best characterized as a flexible inflation targeter, and that inflation expectations have become better anchored since FIT adoption (a finding which echoes our study). The authors use their findings to argue that there is more scope for monetary policy action in India in response to the COVID-19 pandemic. Our paper contributes to this broad strand of literature by providing an India-specific case study. 


\section{EMPIRICAL ANALYSIS}

\section{A. Phillips Curve Estimates}

This section estimates Phillips curves following standard practice in the literature (Gali and Gertler (1999)). We show that historically the headline inflation process has been more backward looking in India compared to other emerging markets, and that core and headline inflation processes are not governed by the same determinants - a finding which differs from the situation in our panel of EMs - suggesting a prominent role for some non-core inflation component in driving the process. We hypothesize here, and provide further evidence later on, that this discrepancy is due to the role of food-price inflation in India.

The emerging market group chosen for our panel analysis includes the following 33 countries: Albania, Bolivia, Botswana, Brazil, Bulgaria, Chile, China, Colombia, Croatia, Dominican Republic, Ecuador, El Salvador, Honduras, Hungary, India, Indonesia, Malaysia, Mexico, Mongolia, Nicaragua, Pakistan, Panama, Paraguay, Peru, Philippines, Poland, Romania, Russia, Rwanda, Serbia, South Africa, Thailand, and Turkey. Other emerging markets are not included in the sample, as they are missing some key variables in the Phillips curve equation, such as import-price inflation. We study the period between 2004Q1 and 2019Q4, due to data-availability considerations. We estimate Phillips curves for headline inflation and core inflation respectively. Given food constitutes a large share of the consumption basket in India, the difference between its headline and core inflation processes implies a role of food price inflation.

We use two measures for inflation expectations: (1) inflation forecasts from the Consensus Forecast, and (2) WEO forecasts. For the Consensus Forecasts in year t, we use 2-year-ahead inflation expectations, and for the WEO forecasts, we use the annual version of the World Economic Studies database and define the forecasts as the expected average change in the CPI index from $t+2$ to $t+5$. Our analysis examines year-on-year changes, according to following equation:

$$
\begin{array}{r}
\pi_{i, t}^{k}=\alpha_{k, i}+\beta_{k} \pi_{i, t}^{k, e}+\beta_{k}^{\text {India }} \pi_{i, t}^{k, e}+\left(1-\beta_{k}\right) \pi_{i, t-4}+\left(1-\beta_{k}-\beta_{k}^{\text {India }}\right) \pi_{i, t-4} \\
+\gamma_{k} Y_{i, t}^{G a p}+\gamma_{k}^{\text {India }} Y_{i, t}^{G a p}+\phi_{k} \pi_{i, t}^{m}+\phi_{k}^{\text {India }} \pi_{i, t}^{m}+\varepsilon_{k, i, t}, \text { for } k \in\{H, C\}
\end{array}
$$

where $\pi_{i, t}^{k}$ is headline $\{\mathrm{H}\}$ (core $\{\mathrm{C}\}$ ) inflation, defined as changes in headline (core) CPI relative to four quarters ago. As the residual terms can be correlated with each other over time, we cluster standard errors at the country level. $\pi_{i, t-4}^{\mathrm{k}, e}$ is expected inflation, as given by two-year-ahead headline inflation forecasts reported by the Consensus Forecast dataset or the World Economic Outlook database. The terms $\beta_{k} \pi_{i, t}^{k, e}+\left(1-\beta_{k}\right) \pi_{i, t-4}$ capture the inflation expectation of a representative firm in the economy and takes a hybrid form to consider different inflation forecasting rules (Gali and Gertler (1999)). We use four-quarter lagged inflation to ensure that the backward-looking part of the inflation process does not incorporate any inflation surprise that directly contributes to a change in headline inflation from time $t-4$ to $t$. We allow the degree of anchoring of inflation expectations to be different between India and other emerging market and developing economies, which is captured by 
the term $\beta_{k}^{\text {India }} \pi_{i, t}^{k, e}{ }^{8} Y_{i, t}^{G a p}$ is the real-time output gap, which is derived from an HP-filtered trend of real GDP and $\pi_{i, t}^{m}$ is the inflation rate of import prices in local currency. ${ }^{9}$ For both, we allow their coefficients to be different between India and other emerging market economies. We include country fixed effects to absorb any measurement error of inflation expectations whose average over time is not zero.

Table 1 reports the estimation results. A consistent pattern is that headline inflation in India has historically been substantially more backward-looking than that of other emerging markets. It is also interesting to note that import-price pass-through to headline inflation has historically been weaker in India, with the coefficient of import price inflation being both smaller and less significant. On the other hand, the core-inflation process is more forward looking, i.e., less sensitive to lagged inflation development, in India. Another salient pattern in Table 1 is that both headline and core inflation are less responsive to the output gap in India than in other emerging market and developing economies. ${ }^{10}$

These patterns suggest that a key non-core component in India (most likely food prices), must have played a significant role in driving the headline inflation process, given the divergence between headline- and core-inflation determinants. In the following sections, it is then natural for us to focus on inflation expectations and the role of food-price inflation to understand the consequence for the inflation process of adopting an inflation targeting regime in India.

\footnotetext{
${ }^{8}$ When equation (1) is estimated for core inflation, we still use headline inflation expectations as a proxy for core inflation expectation, due to data-availability considerations. The difference between headline and core inflation is then absorbed by country fixed effects.

${ }^{9}$ Import price is calculated as the nominal import of goods and services divided by the real import of goods and services, and if this is not feasible, as the nominal import of goods divided by the real import of goods.

10 This result could be due to the relatively small sample size for India. For example, results from state-level analysis in India reported in Behera, Wahi and Kapur (2018) show an upward sloping Phillips curve, although results vary by specification, with a somewhat flat Phillips curve shown in some estimations.
} 
Table 1. Estimation results of Phillips curves

\begin{tabular}{|c|c|c|c|c|}
\hline \multirow[b]{3}{*}{ VARIABLES } & \multirow{2}{*}{\multicolumn{2}{|c|}{$\begin{array}{l}(1) \\
\text { Headline inflation }\end{array}$}} & (3) & (4) \\
\hline & & & \multicolumn{2}{|c|}{ Core inflation } \\
\hline & $\begin{array}{l}\text { WEO } \\
\text { forecast }\end{array}$ & $\begin{array}{l}\text { Consensus } \\
\text { forecast } 1 /\end{array}$ & $\begin{array}{c}\text { WEO } \\
\text { forecast }\end{array}$ & $\begin{array}{c}\text { Consensus } \\
\text { forecast }\end{array}$ \\
\hline Inflation expectation & $\begin{array}{c}0.737^{* * *} \\
(0.025)\end{array}$ & $\begin{array}{l}0.906^{* * *} \\
(0.084)\end{array}$ & $\begin{array}{l}0.658^{* * *} \\
(0.057)\end{array}$ & $\begin{array}{l}0.764^{* * *} \\
(0.084)\end{array}$ \\
\hline Output gap & $\begin{array}{l}0.219^{* * *} \\
(0.057)\end{array}$ & $\begin{array}{l}0.200^{* *} \\
(0.078)\end{array}$ & $\begin{array}{c}0.187^{* * *} \\
(0.056)\end{array}$ & $\begin{array}{l}0.132^{* *} \\
(0.057)\end{array}$ \\
\hline Import price inflation & $\begin{array}{l}0.117^{* * *} \\
(0.018)\end{array}$ & $\begin{array}{l}0.075^{* * *} \\
(0.018)\end{array}$ & $\begin{array}{c}0.067^{* * *} \\
(0.016)\end{array}$ & $\begin{array}{l}0.054^{* * *} \\
(0.020)\end{array}$ \\
\hline $\begin{array}{l}\text { Inflation expectation } \\
\text { - India vs. other EMDEs }\end{array}$ & $\begin{array}{c}-0.381^{* * *} \\
(0.025)\end{array}$ & $\begin{array}{l}-0.359^{* * *} \\
(0.084)\end{array}$ & $\begin{array}{c}0.238^{* * *} \\
(0.057)\end{array}$ & $\begin{array}{c}0.403^{* * *} \\
(0.084)\end{array}$ \\
\hline \multirow{2}{*}{$\begin{array}{l}\text { Output gap } \\
\text { - India vs. other EMDEs } \\
\text { Import price inflation } \\
\text { - India vs. other EMDEs }\end{array}$} & $\begin{array}{c}-0.389^{* * *} \\
(0.057)\end{array}$ & $\begin{array}{l}-0.417^{\star * *} \\
(0.078)\end{array}$ & $\begin{array}{c}-0.214^{* * *} \\
(0.056)\end{array}$ & $\begin{array}{l}-0.214^{* * *} \\
(0.057)\end{array}$ \\
\hline & $\begin{array}{c}-0.097^{* * *} \\
(0.018)\end{array}$ & $\begin{array}{l}-0.054^{* * *} \\
(0.018)\end{array}$ & $\begin{array}{c}0.002 \\
(0.016)\end{array}$ & $\begin{array}{l}-0.005 \\
(0.020)\end{array}$ \\
\hline Constant & $\begin{array}{c}-0.756^{* * *} \\
(0.020)\end{array}$ & $\begin{array}{c}-0.927^{* * *} \\
(0.020)\end{array}$ & $\begin{array}{c}-1.431^{* * *} \\
(0.111)\end{array}$ & $\begin{array}{c}-1.140^{* * *} \\
(0.118)\end{array}$ \\
\hline Observations & 1,947 & 1,131 & 1,479 & 1,088 \\
\hline \multicolumn{5}{|c|}{$\begin{array}{l}\text { Note: } 1 \text { / Due to the coverage of the Consensus Forecast, the sample has fewer } \\
\text { countries than in Column (1) and includes } 26 \text { countries: Albania, Bolivia, Brazil, Bulgaria, } \\
\text { Chile, China, Colombia, Croatia, Dominican Republic, Ecuador, El Salvador, Honduras, } \\
\text { Hungary, India, Indonesia, Malaysia, Mexico, Nicaragua, Pakistan, Panama, Paraguay, } \\
\text { Peru, Philippines, Poland, Romania, Russia, Serbia, Thailand, and Turkey. }\end{array}$} \\
\hline Sources: Authors' calculat & & & & \\
\hline
\end{tabular}

\section{B. Changes in the Anchoring of Inflation Expectations}

This section presents two empirical patterns to suggest that inflation expectations have become better anchored since early 2015 - the time India adopted its inflation targeting regime. ${ }^{11}$ We construct a measure of inflation surprises and a revision in medium-term inflation expectations, by exploiting the structure of the Consensus Economics surveys about inflation forecasts. Specifically, an inflation surprise is defined as a revision in the current survey regarding the expected change in headline CPI from January to December in the current calendar year compared with the previous survey. A revision in the medium-term inflation forecast is defined in a similar way and based on the inflation forecast regarding the expected change in CPI from January to December, 2 years ahead.

Figure 1 presents the distribution of these surprises, based on the following idea: if inflation expectations are fully anchored around central bank targets, inflation surprises in the near term should have little impact on medium-term inflation projections; we should then expect a very tight distribution of medium-term inflation-forecast revisions, clustered around zero. In the figure, the revisions in other emerging markets serve as a benchmark, and there is clearly

\footnotetext{
${ }^{11}$ In the baseline exercises, we treat India's FIT adoption date as corresponding to the Monetary Policy Framework Agreement, which took place in February 2015. The results shown in the Appendix suggest that the main findings are robust to choosing a different structural break point in time.
} 
a narrowing of the distribution in India from 2015 and thereafter. ${ }^{12}$ This suggests that inflation expectations in India were less anchored compared with other emerging markets before 2015; whereas from 2015 and thereafter anchoring has been similar.

Figure 1 Distribution of Revisions in Two-Year Ahead Inflation Expectations: India vs. Other Emerging Markets
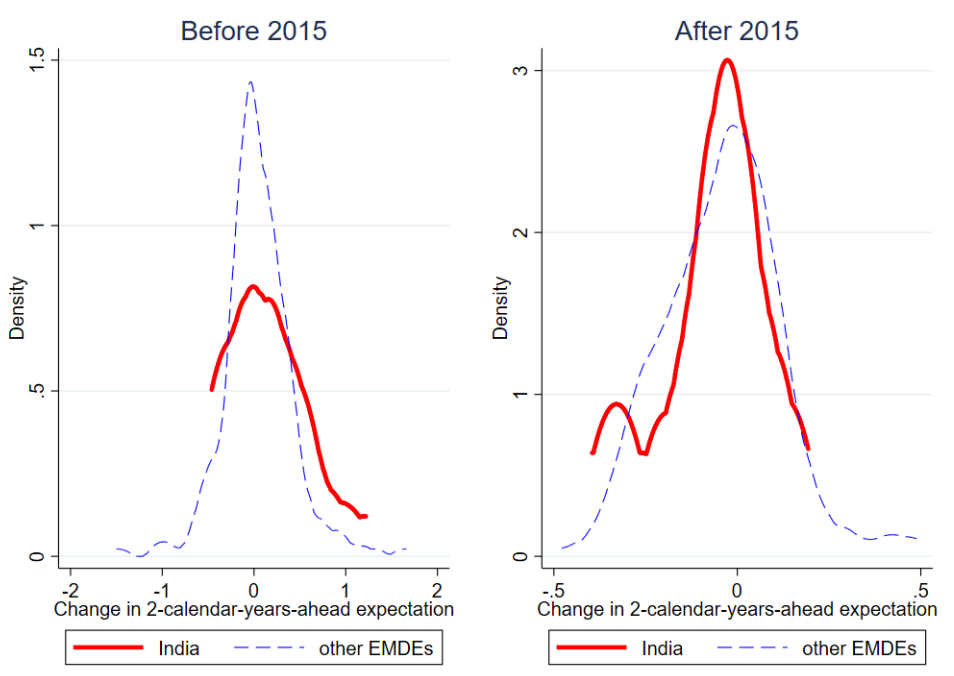

Sources: Consensus Forecast database; and Authors' calculations.

Figure 2 exploits the relationship between the inflation surprise and the revision in mediumterm inflation expectations. The idea is very similar to what we show in Figure 1: the more anchored are inflation expectations, the lower the sensitivity to an inflation surprise. For illustrative purposes, we compare India with Chile and Poland, both of whom adopted FIT regimes earlier than India. ${ }^{13}$

\footnotetext{
${ }^{12}$ Here and after, whenever we use the term "after 2015", the time period under consideration includes 2015.

${ }^{13}$ The selection of comparator countries here is purely illustrative and serves to add additional context to the entire-EM comparison exercise which is presented in Figure 1.
} 


\section{Figure 2 Correlation Between Revisions in Inflation Forecasts for Current Year and Two-Years Ahead}

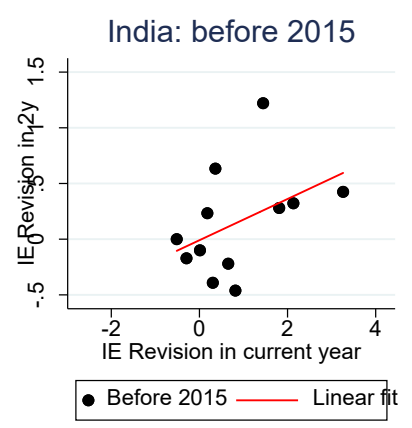

India: after 2015

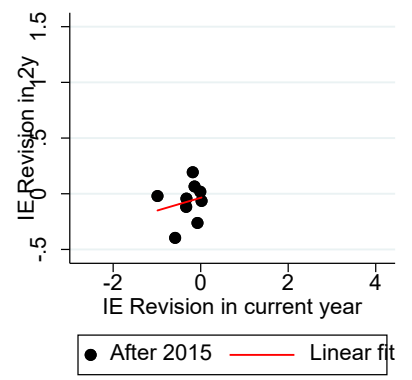

Chile: before 2015

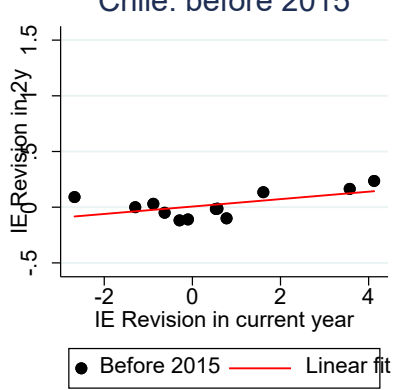

Chile: after 2015

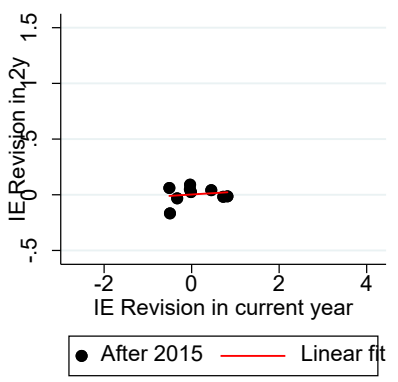

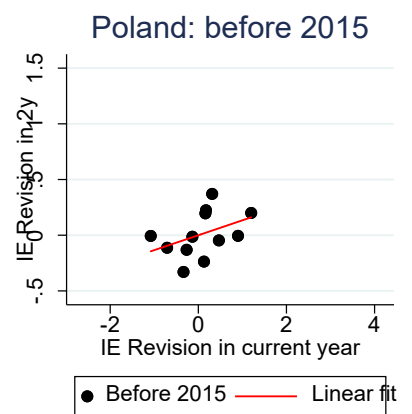

Poland: after 2015

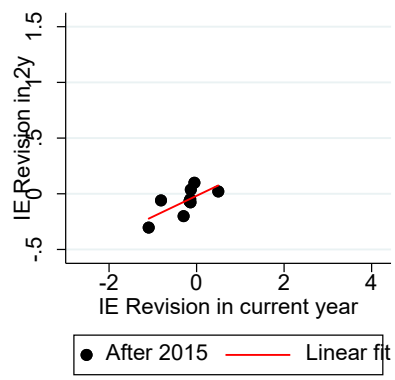

Sources: Consensus Forecast database; and Authors' calculations Note: "after 2015" includes 2015.

In Chile, two-year ahead inflation expectations were well-anchored and responded very little to inflation surprises both before 2015 and thereafter. By contrast, the sensitivity of mediumterm inflation expectations to inflation news declined in India, since 2015. The pattern in Poland suggests that its sensitivity was largely unchanged before 2015 and thereafter, pointing to a role of domestic factors in India causing the change in the anchoring of inflation expectations.

\section{Second-Round Effects: The Role of Food Inflation}

In this section, we study whether second-round effects became weaker after 2015, by examining the relationship between core and headline inflation (and, later, food inflation). Second-round effects are useful in gauging the anchoring of inflation expectations, with the basic idea being that if inflation expectations are more anchored, it is more likely for changes in headline inflation to be transitory. Following Cecchetti and Moessner (2008), and Anand, Ding, and Tulin (2014), we study the response of headline and core inflation to the gap between these two series - put differently, we study their propensity to move back towards one another. 
Specifically, we estimate the following equations with monthly data:

$$
\begin{gathered}
\pi_{i, t}^{\text {Headline }}-\pi_{i, t-12}^{\text {Headline }}=\alpha^{1}+\beta^{1}\left(\pi_{i, t-12}^{\text {Headline }}-\pi_{i, t-12}^{\text {Core }}\right)+\varepsilon_{\text {Headline }, i, t}, \\
\pi_{i, t}^{\text {Core }}-\pi_{i, t-12}^{\text {Core }}=\alpha^{2}+\beta^{2}\left(\pi_{i, t-12}^{\text {Headline }}-\pi_{i, t-12}^{\text {Core }}\right)+\varepsilon_{\text {Core }, i, t}
\end{gathered}
$$

In equation (2), parameter $\beta^{1}$ captures the degree to which deviations of headline inflation from core are resolved through subsequent changes in headline inflation - that is, the degree to which headline inflation reverts to core inflation (evidence of a lack of second-round passthrough). A coefficient of -1 would indicate that headline fully reverts to core within a year. The same concept applies to equation (3): if core inflation reverts to headline inflation within one year, parameter $\beta^{2}$ would be equal to 1 .

To assess the presence of any possible structural breaks in the reversion properties between core and headline inflation, we estimate equations (2) and (3) for sample periods before and after the adoption of FIT. Table 2 reports the estimation results for our baseline specification, where we define the pre-FIT period as that before January 2015. In the pre-FIT period, core inflation tended to increase (decline) when headline was above (below) core, suggesting second-round effects from non-core CPI inflation into core inflation. By contrast, headline inflation was generally unresponsive to deviations vis-à-vis core inflation over this same period.

There has been a structural break in parameter estimates since 2015. In the more recent sample period, core inflation has not tended towards headline inflation (no evidence of second-round effects), whereas headline inflation has tended towards core. ${ }^{14}$

Food inflation seemed to play a role in this structural break. Estimating the same regression as in equations (2) and (3), but with food inflation as the dependent variable, we see a substantial tendency for food inflation to decline relative to the headline inflation in the recent period whenever there is a positive gap between headline and core inflation, as is shown in Table 3, column 2. This was not the case before 2015 (column 1), likely indicating that there have been persistent negative shocks to food prices over the most recent period. The same finding holds when considering instead the change in the relative price of food in India (columns 3 and 4), where this is defined as the ratio of food price over headline CPI.

\footnotetext{
${ }^{14}$ The coefficient of the gap between headline and core inflation rates in the headline inflation equation is significantly smaller than -1 , and that in the core inflation is slightly negative (though insignificant). These should reflect other inflation drivers not explicitly controlled for in the regression.
} 
Table 2 Estimation of Second-Round-Effect Equations

\begin{tabular}{|c|c|c|c|c|}
\hline VARIABLES & $\begin{array}{c}(1) \\
\text { Core } \\
\text { inflation } \\
\text { 2002M1 }-2014 \mathrm{M} 12\end{array}$ & $\begin{array}{c}(2) \\
\text { Core } \\
\text { inflation } \\
2015 \mathrm{M} 1-2018 \mathrm{M} 3\end{array}$ & $\begin{array}{c}(3) \\
\text { Headline } \\
\text { inflation } \\
\text { 2002M1 - 2014M12 }\end{array}$ & $\begin{array}{c}(4) \\
\text { Headline } \\
\text { inflation } \\
\text { 2015M1 - 2018M3 }\end{array}$ \\
\hline Headline - core_t -12 & $\begin{array}{l}1.044^{* * *} \\
(0.087)\end{array}$ & $\begin{array}{l}-0.183 \\
(0.135)\end{array}$ & $\begin{array}{l}-0.026 \\
(0.042)\end{array}$ & $\begin{array}{c}-1.450^{* * *} \\
(0.177)\end{array}$ \\
\hline Constant & $\begin{array}{c}0.209 \\
(1.538)\end{array}$ & $\begin{array}{c}0.300 \\
(0.543)\end{array}$ & $\begin{array}{l}-0.062 \\
(0.738)\end{array}$ & $\begin{array}{l}-0.138 \\
(0.713)\end{array}$ \\
\hline $\begin{array}{l}\text { Observations } \\
\text { R-squared }\end{array}$ & $\begin{array}{c}156 \\
0.483 \\
\end{array}$ & $\begin{array}{r}39 \\
0.048 \\
\end{array}$ & $\begin{array}{c}156 \\
0.002 \\
\end{array}$ & $\begin{array}{r}39 \\
0.645 \\
\end{array}$ \\
\hline
\end{tabular}

Could such a structural break in India's inflation process be caused by a global factor? To explore this possibility, we study the dynamics separately for the global and domestic components of relative food price inflation, to see whether their response to the headlineinflation-core-inflation gap changed after 2015. To construct the domestic component of relative food price, for 9 Asian countries, we regress the relative food price measure on country and year fixed effects, and the residual of this regression can be interpreted as the domestic component of relative food price, as any global trend in food price has been taken out. ${ }^{15}$ By focusing on Asian countries, we consider regional shocks that can influence their food prices.

Results in Table 3 (columns 5 and 6) suggest that the global component of the relative price of food is not responsive to the gap between headline inflation and core inflation, and there is no structural break. By contrast, India's domestic component of relative food price-shown in columns 7 and 8 - played a key role in the negative response of headline inflation to the gap after 2015, which was not the case before 2015 .

Given a lack of consensus regarding what date should be used to correspond to define the adoption of FIT (e.g. the agreement between the RBI and the government, or the formation of the Monetary Policy Committee), we conduct robustness tests by using alternative dates to split the sample period and report the results in the Appendix. As shown there, results are little changed by shifting the break date forward or backward by a year. It is not clear whether this finding supports the hypothesis that FIT adoption played a role in the anchoring of core inflation, or whether it suggests that another factor - such as the persistent decline in food prices seen in recent years - is more important. In this regard, recent work by Raj and others (2020) tends to underscore the importance of food-price shocks in the breakdown of the headline-core revertability.

\footnotetext{
${ }^{15}$ The 9 Asian countries include China, India, Indonesia, Korea, Malaysia, Pakistan, Philippines, Singapore and Thailand.
} 
Table 3 Estimation of Food Price Response to the Headline-Core-Inflation Gap

\begin{tabular}{|c|c|c|c|c|}
\hline VARIABLES & $\begin{array}{c}(1) \\
\text { Food } \\
\text { inflation } \\
\text { 2002M1 - 2014M12 }\end{array}$ & $\begin{array}{c}(2) \\
\text { Food } \\
\text { inflation } \\
2015 \mathrm{M} 1-2018 \mathrm{M} 3 \\
\end{array}$ & $\begin{array}{c}\text { (3) } \\
\text { Relative } \\
\text { food inflation } \\
\text { 2002M1 - 2014M12 }\end{array}$ & $\begin{array}{c}\text { (4) } \\
\text { Relative } \\
\text { food inflation } \\
2015 \mathrm{M} 1-2018 \mathrm{M} 3\end{array}$ \\
\hline Headline - core_t - 12 & $\begin{array}{c}0.057 \\
(0.104)\end{array}$ & $\begin{array}{c}-2.740^{* * *} \\
(0.344)\end{array}$ & $\begin{array}{c}0.044 \\
(0.063)\end{array}$ & $\begin{array}{c}-1.218^{* * *} \\
(0.181)\end{array}$ \\
\hline Constant & $\begin{array}{l}-0.616 \\
(2.154)\end{array}$ & $\begin{array}{l}-0.990 \\
(1.382)\end{array}$ & $\begin{array}{l}-0.327 \\
(1.301)\end{array}$ & $\begin{array}{c}-0.469 \\
(0.730)\end{array}$ \\
\hline $\begin{array}{l}\text { Observations } \\
\text { R-squared }\end{array}$ & $\begin{array}{c}96 \\
0.003\end{array}$ & $\begin{array}{c}40 \\
0.625\end{array}$ & $\begin{array}{c}96 \\
0.005\end{array}$ & $\begin{array}{c}39 \\
0.550\end{array}$ \\
\hline VARIABLES & $\begin{array}{c}\text { (5) } \\
\text { Global } \\
\text { component } \\
\text { 2002M1 - 2014M12 }\end{array}$ & $\begin{array}{c}\text { (6) } \\
\text { Global } \\
\text { component } \\
2015 \mathrm{M} 1-2018 \mathrm{M} 3 \\
\end{array}$ & $\begin{array}{c}\text { (7) } \\
\text { India } \\
\text { component } \\
2002 \mathrm{M} 1-2014 \mathrm{M} 12 \\
\end{array}$ & $\begin{array}{c}\text { (8) } \\
\text { India } \\
\text { component } \\
\text { 2015M1 - 2018M3 } \\
\end{array}$ \\
\hline Headline - core_t - 12 & $\begin{array}{c}0.001 \\
(0.024)\end{array}$ & $\begin{array}{c}0.212 \\
(0.210)\end{array}$ & $\begin{array}{c}0.052 \\
(0.060)\end{array}$ & $\begin{array}{c}-1.455^{\star * *} \\
(0.271)\end{array}$ \\
\hline Constant & $\begin{array}{c}0.078 \\
(0.441)\end{array}$ & $\begin{array}{l}-0.061 \\
(0.843)\end{array}$ & $\begin{array}{l}-0.223 \\
(1.252)\end{array}$ & $\begin{array}{c}-0.291 \\
(1.091)\end{array}$ \\
\hline $\begin{array}{l}\text { Observations } \\
\text { R-squared }\end{array}$ & $\begin{array}{c}145 \\
0.000\end{array}$ & $\begin{array}{c}40 \\
0.026\end{array}$ & $\begin{array}{c}96 \\
0.008\end{array}$ & $\begin{array}{c}39 \\
0.438\end{array}$ \\
\hline $\begin{array}{l}\text { Standard errors in pare } \\
{ }^{* \star *} p<0.01,{ }^{* *} p<0.05 \\
\text { Source: Authors' calcul }\end{array}$ & $\begin{array}{l}\text { entheses } \\
{ }^{*} p<0.1 \\
\text { lations }\end{array}$ & & & \\
\hline
\end{tabular}

To summarize the findings in this section, we show that the domestic component of relative food-price inflation contributed to weaker second-round effects after 2015. It has thus become less likely for headline inflation to deviate from core inflation persistently, and consequently, this implies a more limited impact on medium-term inflation expectations of any given short-term development in headline inflation. This could be the result of FIT adoption, or simply a series of low food-inflation outturns in recent years.

\section{POLICY IMPLICATIONS: MODEL-BASED SIMULATIONS}

How does the change in the degree of anchoring of inflation expectations affect the conduct of monetary policy in India? We argue that the trade-off between stabilizing inflation and closing the output gap is improved, and with more anchored inflation expectations, the Reserve Bank of India would need to tighten interest rate less aggressively to return inflation to target when there is a rise in headline inflation driven by food prices, as compared to the situation where expectations are less well anchored. To illustrate the quantitative relevance of these changes, we conduct simulations using a semi-structural model of the Indian economy, which is closely related to the Reserve Bank of India's benchmark macroeconomic model, as described in Benes and others (2017).

We adjust the baseline parameterization of the Phillips curve in the model and consider the effects of a persistent increase in inflation in India under both the baseline and alternative Phillips curve parameterizations. The Phillips curve equation for core inflation in the model is given by:

$$
\pi_{t}^{\mathrm{C}}=\sigma_{1} \pi_{t+4}^{\mathrm{C}}+\left(1-\sigma_{1}\right) \pi_{t-1}^{\mathrm{C}}+\sigma_{2}\left(Y_{t}^{\text {Gap }}+\sigma_{3} Z_{t}^{\text {Gap }}\right)+\sigma_{4}\left(\pi_{t}^{H}-\pi_{t}^{\mathrm{C}}\right)+\varepsilon_{t},
$$


where $\pi_{t}^{\mathrm{C}}$ is core inflation at period $t$ (subscripts $(t-1)$ and $(t+4)$ denote one quarter lag, and four-quarter-ahead, model-consistent inflation expectations, respectively), $Y_{t}^{G a p}$ is the output gap, $Z_{t}^{G a p}$ is a real exchange rate gap which is defined as the deviation of the current-period real exchange rate from its equilibrium level, and is intended to capture exchange-rate passthrough. Finally, the term $\left(\pi_{t}^{H}-\pi_{t}^{\mathrm{C}}\right)$ introduces a direct link between headline and core inflation - the higher is parameter $\sigma_{4}$, the larger the passthrough from headline inflation into core inflation (second-round effects).

In the baseline calibration of the model, the parameter on the forward-looking element of core inflation $\left(\sigma_{1}\right)$ is 0.33 , and the immediate passthrough to core from differences vis-à-vis headline inflation (given by $\sigma_{4}$ ) is $0.05 .{ }^{16}$ We term the scenario using the baseline calibration the 'more anchored inflation' variant. Then, we reduce the anchoring of inflation expectations by reducing $\sigma_{1}(=0.05)$ and increasing $\sigma_{4}(=0.25)$. This calibration is termed the 'less anchored inflation' variant. All other equations in the model, and their calibrations, are unchanged between the two simulations. ${ }^{17}$

Using these two different calibrations of the Phillips curve, we consider two simulations. They both start in 2019Q2, and core inflation is assumed to rise gradually to 6.0 percent, with food and fuel inflation rising to 7.0 percent, by 2020Q1. The two variants of the model dictate the future paths of all non-inflation variables at all horizons, according to the relationships described by model equations - from 2020Q2 onwards, the model also dictates the path for core and headline inflation rates. The results are shown in Figure 3. To bring down high inflation in these scenarios, interest rates need to be increased. However, this increase must be larger in the scenario (model calibration) where inflation expectations are less anchored. This larger increase in interest rates results in a larger output loss for the economy. By contrast, inflation can be returned to the target with smaller interest-rate increases (and lower output losses) when inflation expectations are more anchored.

Additional variants of this class of model can be derived which emphasize the role of endogenous credibility. Although the scenarios considered here do not include such a mechanism, if the credibility of the central bank is assumed to improve (deteriorate) as it continues to achieve (miss) its inflation target over time, then the anchoring of inflation expectations can be shown to improve (deteriorate) as a result. In the context of the simulations considered here, including endogenous central bank credibility would then strengthen the results shown in Figure 3, as greater (lesser) achievement of the inflation target over time would add to (detract from) credibility, and further contribute to anchoring (de-anchoring) of expectations.

\footnotetext{
${ }^{16}$ All other parameters in the model - those pertaining to the output gap $\left(Y_{t}^{G a p}\right)$ and real effective exchange rate gap $\left(Z_{t}^{G a p}\right)$ are unchanged between the two calibrations considered here.

${ }^{17}$ All other model equations are documented in Benes and others (2017) and excluded here for brevity.
} 
Figure 3. Implications of Inflation-Expectations Anchoring: Model Simulation Results
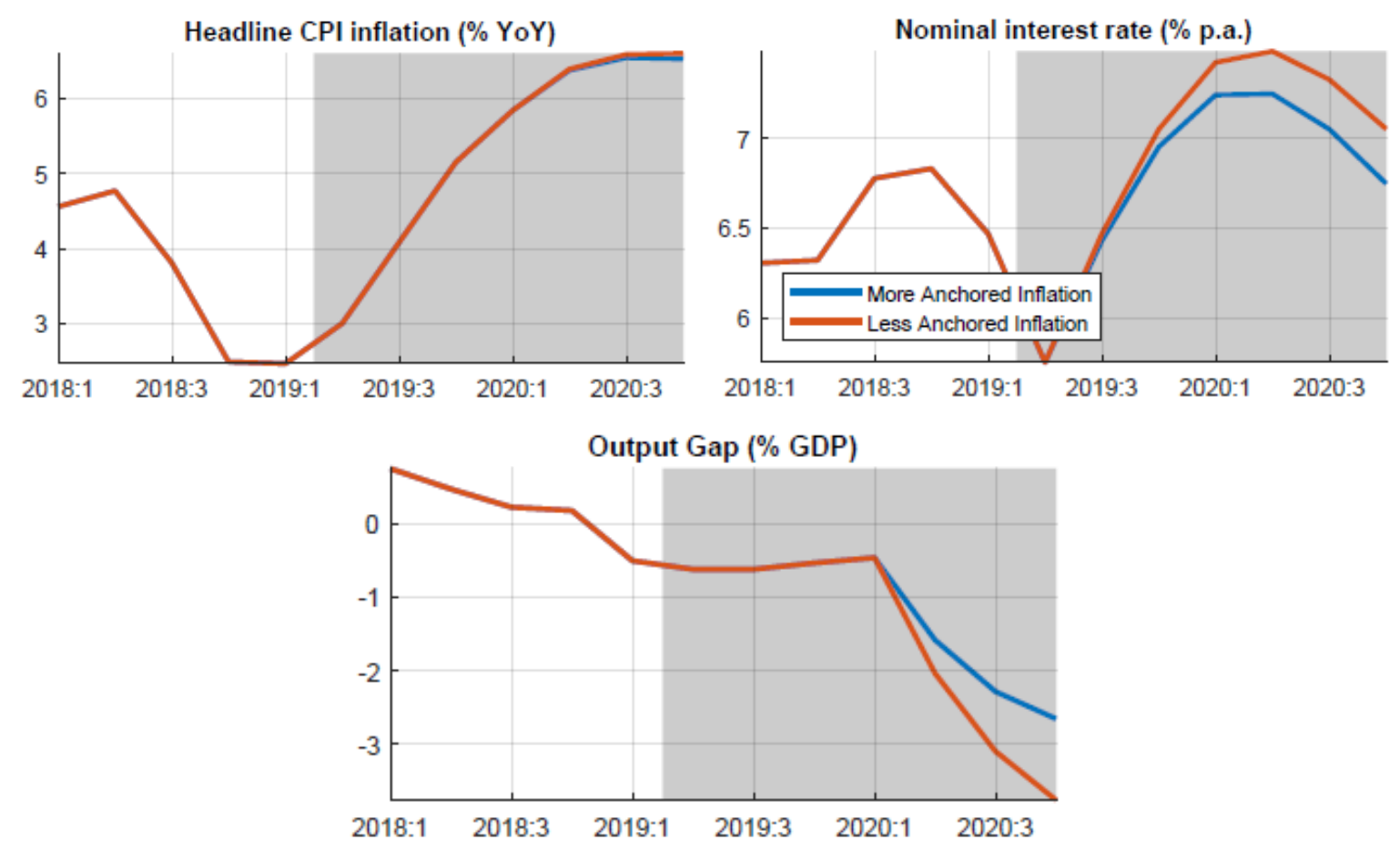

Source: Authors' calculations

\section{Conclusion}

In this paper, we document a recent shift in the inflation process in India, which broadly coincided with the adoption of FIT. We try to understand whether this shift was driven by domestic or global factors, given there is not a consensus on this issue.

To do this, we document several empirical patterns suggesting that inflation expectations became more anchored, and domestic factors played a role. First, we estimate the headline and core inflation processes in India and compare them with those of other emerging markets. We find that the passthrough of import prices to headline inflation is weaker in India than in other emerging markets. Also, headline inflation was much more backward looking in India than in other countries, mainly driven by the non-core-inflation component. Then, we show that inflation expectations have become more anchored based on two patterns. First, after 2015, core inflation became less likely to converge to headline inflation. Second, we find that medium-term inflation expectations in India were less likely to be revised and became less sensitive to inflation surprises.

We argue that domestic factors play a role in these structural changes. We show that food price inflation experienced a shift in its responsiveness to the gap between headline and core inflation, which contributes to more anchored headline inflation. We highlight that this change comes from the domestic rather than the international component of India's food price inflation. 
Finally, we use a semi-structural model calibrated to the Indian economy to show that the degree of anchoring of inflation expectations is quantitatively significant for the cost of stabilizing inflation. The presence of second-round effects and more backward-looking inflation are shown to make it more costly for monetary policy makers to return inflation to target, when faced with persistent increases in core and food/fuel inflation.

One caveat for our analysis is that we do not rule out a possibility that subdued food price inflation caused by persistent supply shocks stood behind the patterns we document. Nevertheless, our findings support the notion that FIT is performing well in India. 


\section{Appendix: Robustness of Results to the Structural Break Point}

This section reports results to suggest that the convergence between core and headline inflation rates does not depend on how we split the sample period. Table A.1-A.4 show the robustness of the findings of main text Tables 2 and 3 with respect to alternative samplebreak dates, and Figures A.1-A.4 the robustness of the patterns in Figure 1 and 2.

Table A.1 Estimation of Second-Round-Effect Equations: Split the Sample at 2013 M12

\begin{tabular}{|c|c|c|c|c|}
\hline VARIABLES & $\begin{array}{c}\text { (1) } \\
\text { Core } \\
\text { inflation } \\
\text { 2002M1 - 2013M12 }\end{array}$ & $\begin{array}{c}(2) \\
\text { Core } \\
\text { inflation } \\
\text { 2014M1 - 2018M3 }\end{array}$ & $\begin{array}{c}(3) \\
\text { Headline } \\
\text { inflation } \\
\text { 2002M1 - 2013M12 }\end{array}$ & $\begin{array}{c}\text { (4) } \\
\text { Headline } \\
\text { inflation } \\
\text { 2014M1 - 2018M3 }\end{array}$ \\
\hline Headline - core_t - 12 & $\begin{array}{l}1.059^{* * *} \\
(0.090)\end{array}$ & $\begin{array}{l}-0.195^{*} \\
(0.107)\end{array}$ & $\begin{array}{l}-0.010 \\
(0.041)\end{array}$ & $\begin{array}{c}-1.409^{* * *} \\
(0.148)\end{array}$ \\
\hline Constant & $\begin{array}{c}0.695 \\
(1.652)\end{array}$ & $\begin{array}{l}-0.179 \\
(0.504)\end{array}$ & $\begin{array}{c}0.376 \\
(0.755)\end{array}$ & $\begin{array}{l}-0.335 \\
(0.698)\end{array}$ \\
\hline $\begin{array}{l}\text { Observations } \\
\text { R-squared }\end{array}$ & $\begin{array}{c}144 \\
0.492\end{array}$ & $\begin{array}{c}51 \\
0.064\end{array}$ & $\begin{array}{c}144 \\
0.000\end{array}$ & $\begin{array}{c}51 \\
0.649\end{array}$ \\
\hline
\end{tabular}

Standard errors in parentheses

${ }^{* * *} p<0.01,{ }^{* *} p<0.05,{ }^{*} p<0.1$

Source: Authors' calculations

Table A.2 Estimation of Food Price Response to the Headline-Core-Inflation Gap: Split the Sample at 2013M12

\begin{tabular}{|c|c|c|c|c|}
\hline VARIABLES & $\begin{array}{c}\text { (1) } \\
\text { Food } \\
\text { inflation } \\
\text { 2002M1 }-2013 \mathrm{M} 12\end{array}$ & $\begin{array}{c}\text { (2) } \\
\text { Food } \\
\text { inflation } \\
2014 \mathrm{M} 1-2018 \mathrm{M} 3\end{array}$ & $\begin{array}{c}(3) \\
\text { Relative } \\
\text { food inflation } \\
\text { 2002M1 }-2013 \mathrm{M} 12\end{array}$ & $\begin{array}{c}(4) \\
\text { Relative } \\
\text { food inflation } \\
2014 \mathrm{M} 1-2018 \mathrm{M} 3\end{array}$ \\
\hline Headline - core_t - 12 & $\begin{array}{c}0.088 \\
(0.105)\end{array}$ & $\begin{array}{c}-2.593^{* * *} \\
(0.290)\end{array}$ & $\begin{array}{c}0.058 \\
(0.065)\end{array}$ & $\begin{array}{c}-1.165^{\star * *} \\
(0.146)\end{array}$ \\
\hline Constant & $\begin{array}{c}0.526 \\
(2.311)\end{array}$ & $\begin{array}{l}-0.885 \\
(1.363)\end{array}$ & $\begin{array}{c}0.059 \\
(1.436)\end{array}$ & $\begin{array}{l}-0.210 \\
(0.688)\end{array}$ \\
\hline $\begin{array}{l}\text { Observations } \\
\text { R-squared }\end{array}$ & $\begin{array}{c}84 \\
0.008\end{array}$ & $\begin{array}{c}52 \\
0.615\end{array}$ & $\begin{array}{c}84 \\
0.009\end{array}$ & $\begin{array}{c}51 \\
0.567\end{array}$ \\
\hline VARIABLES & $\begin{array}{c}(5) \\
\text { Global } \\
\text { component } \\
\text { 2002M1 - 2013M12 }\end{array}$ & $\begin{array}{c}\text { (6) } \\
\text { Global } \\
\text { component } \\
\text { 2014M1 - 2018M3 }\end{array}$ & $\begin{array}{c}(7) \\
\text { India } \\
\text { component } \\
\text { 2002M1 - 2013M12 }\end{array}$ & $\begin{array}{c}\text { (8) } \\
\text { India } \\
\text { component } \\
\text { 2014M1 - 2018M3 }\end{array}$ \\
\hline Headline - core_t - 12 & $\begin{array}{c}0.003 \\
(0.025)\end{array}$ & $\begin{array}{c}0.054 \\
(0.146)\end{array}$ & $\begin{array}{c}0.065 \\
(0.063)\end{array}$ & $\begin{array}{c}-1.235^{\star * *} \\
(0.206)\end{array}$ \\
\hline Constant & $\begin{array}{c}0.108 \\
(0.474)\end{array}$ & $\begin{array}{l}-0.157 \\
(0.688)\end{array}$ & $\begin{array}{c}0.147 \\
(1.379)\end{array}$ & $\begin{array}{c}0.041 \\
(0.973)\end{array}$ \\
\hline $\begin{array}{l}\text { Observations } \\
\text { R-squared }\end{array}$ & $\begin{array}{c}133 \\
0.000\end{array}$ & $\begin{array}{c}52 \\
0.003\end{array}$ & $\begin{array}{c}84 \\
0.013\end{array}$ & $\begin{array}{c}51 \\
0.423\end{array}$ \\
\hline
\end{tabular}

Standard errors in parentheses

${ }^{* * *} p<0.01,{ }^{* *} p<0.05,{ }^{*} p<0.1$

Source: Authors' calculations 
Table A.3 Estimation of Second-Round-Effect Equations: Split the Sample at 2015M12

\begin{tabular}{|c|c|c|c|c|}
\hline VARIABLES & $\begin{array}{c}\text { (1) } \\
\text { Core } \\
\text { inflation } \\
\text { 2002M1 - 2015M12 }\end{array}$ & $\begin{array}{c}(2) \\
\text { Core } \\
\text { inflation } \\
2016 \mathrm{M} 1-2018 \mathrm{M} 3\end{array}$ & $\begin{array}{c}\text { (3) } \\
\text { Headline } \\
\text { inflation } \\
\text { 2002M1 }-2015 \mathrm{M} 12\end{array}$ & $\begin{array}{c}(4) \\
\text { Headline } \\
\text { inflation } \\
\text { 2016M1 }-2018 \mathrm{M} 3\end{array}$ \\
\hline Headline - core_t - 12 & $\begin{array}{c}1.035^{* * *} \\
(0.084)\end{array}$ & $\begin{array}{l}-0.067 \\
(0.201)\end{array}$ & $\begin{array}{l}-0.035 \\
(0.041)\end{array}$ & $\begin{array}{c}-1.531^{* \star *} \\
(0.269)\end{array}$ \\
\hline Constant & $\begin{array}{c}0.226 \\
(1.436)\end{array}$ & $\begin{array}{c}0.164 \\
(0.672)\end{array}$ & $\begin{array}{c}0.023 \\
(0.705)\end{array}$ & $\begin{array}{l}-0.810 \\
(0.902)\end{array}$ \\
\hline $\begin{array}{l}\text { Observations } \\
\text { R-squared }\end{array}$ & $\begin{array}{c}168 \\
0.478\end{array}$ & $\begin{array}{c}27 \\
0.004\end{array}$ & $\begin{array}{c}168 \\
0.004\end{array}$ & $\begin{array}{c}27 \\
0.564\end{array}$ \\
\hline
\end{tabular}

Table A.4 Estimation of Food Price Response to the Headline-Core-Inflation Gap: Split the Sample at 2015M12

\begin{tabular}{|c|c|c|c|c|}
\hline VARIABLES & $\begin{array}{c}\text { (1) } \\
\begin{array}{c}\text { Food } \\
\text { inflation }\end{array} \\
\text { 2002M1 }-2015 \mathrm{M} 12\end{array}$ & $\begin{array}{c}(2) \\
\text { Food } \\
\text { inflation } \\
2016 \mathrm{M} 1-2018 \mathrm{M} 3 \\
\end{array}$ & $\begin{array}{c}(3) \\
\text { Relative } \\
\text { food inflation } \\
\text { 2002M1 }-2015 \mathrm{M} 12\end{array}$ & $\begin{array}{c}\text { (4) } \\
\text { Relative } \\
\text { food inflation } \\
2016 \mathrm{M} 1-2018 \mathrm{M} 3\end{array}$ \\
\hline Headline - core_t - 12 & $\begin{array}{c}0.035 \\
(0.101)\end{array}$ & $\begin{array}{c}-2.833^{* * *} \\
(0.524)\end{array}$ & $\begin{array}{c}0.034 \\
(0.060)\end{array}$ & $\begin{array}{c}-1.332^{* * *} \\
(0.282)\end{array}$ \\
\hline Constant & $\begin{array}{l}-0.463 \\
(1.982)\end{array}$ & $\begin{array}{l}-1.873 \\
(1.754)\end{array}$ & $\begin{array}{l}-0.273 \\
(1.177)\end{array}$ & $\begin{array}{l}-0.815 \\
(0.944)\end{array}$ \\
\hline $\begin{array}{l}\text { Observations } \\
\text { R-squared }\end{array}$ & $\begin{array}{c}108 \\
0.001\end{array}$ & $\begin{array}{c}28 \\
0.529\end{array}$ & $\begin{array}{c}108 \\
0.003\end{array}$ & $\begin{array}{c}27 \\
0.472\end{array}$ \\
\hline VARIABLES & $\begin{array}{c}\text { (5) } \\
\text { Global } \\
\text { component } \\
\text { 2002M1 - 2015M12 }\end{array}$ & $\begin{array}{c}\text { (6) } \\
\text { Global } \\
\text { component } \\
\text { 2016M1 - 2018M3 }\end{array}$ & $\begin{array}{c}(7) \\
\text { India } \\
\text { component } \\
\text { 2002M1 - 2015M12 }\end{array}$ & $\begin{array}{c}(8) \\
\text { India } \\
\text { component } \\
\text { 2016M1 - 2018M3 }\end{array}$ \\
\hline Headline - core_t - 12 & $\begin{array}{l}-0.000 \\
(0.024)\end{array}$ & $\begin{array}{l}0.597^{*} \\
(0.330)\end{array}$ & $\begin{array}{c}0.044 \\
(0.058)\end{array}$ & $\begin{array}{c}-1.991^{* * *} \\
(0.429)\end{array}$ \\
\hline Constant & $\begin{array}{c}0.058 \\
(0.413)\end{array}$ & $\begin{array}{c}0.098 \\
(1.104)\end{array}$ & $\begin{array}{l}-0.162 \\
(1.131)\end{array}$ & $\begin{array}{l}-0.707 \\
(1.435)\end{array}$ \\
\hline $\begin{array}{l}\text { Observations } \\
\text { R-squared }\end{array}$ & $\begin{array}{c}157 \\
0.000\end{array}$ & $\begin{array}{c}28 \\
0.112\end{array}$ & $\begin{array}{c}108 \\
0.005\end{array}$ & $\begin{array}{c}27 \\
0.463\end{array}$ \\
\hline $\begin{array}{l}\text { Standard errors in par } \\
{ }^{* * *} p<0.01,{ }^{* *} p<0.05 \\
\text { Source: Authors' calcul }\end{array}$ & $\begin{array}{l}\text { entheses } \\
{ }^{*} p<0.1 \\
\text { dlations }\end{array}$ & & & \\
\hline
\end{tabular}


Figure A.1 Distribution of Revisions in Two-Year Ahead Inflation Expectations: India vs. Other Emerging Markets, Split the Sample in 2014
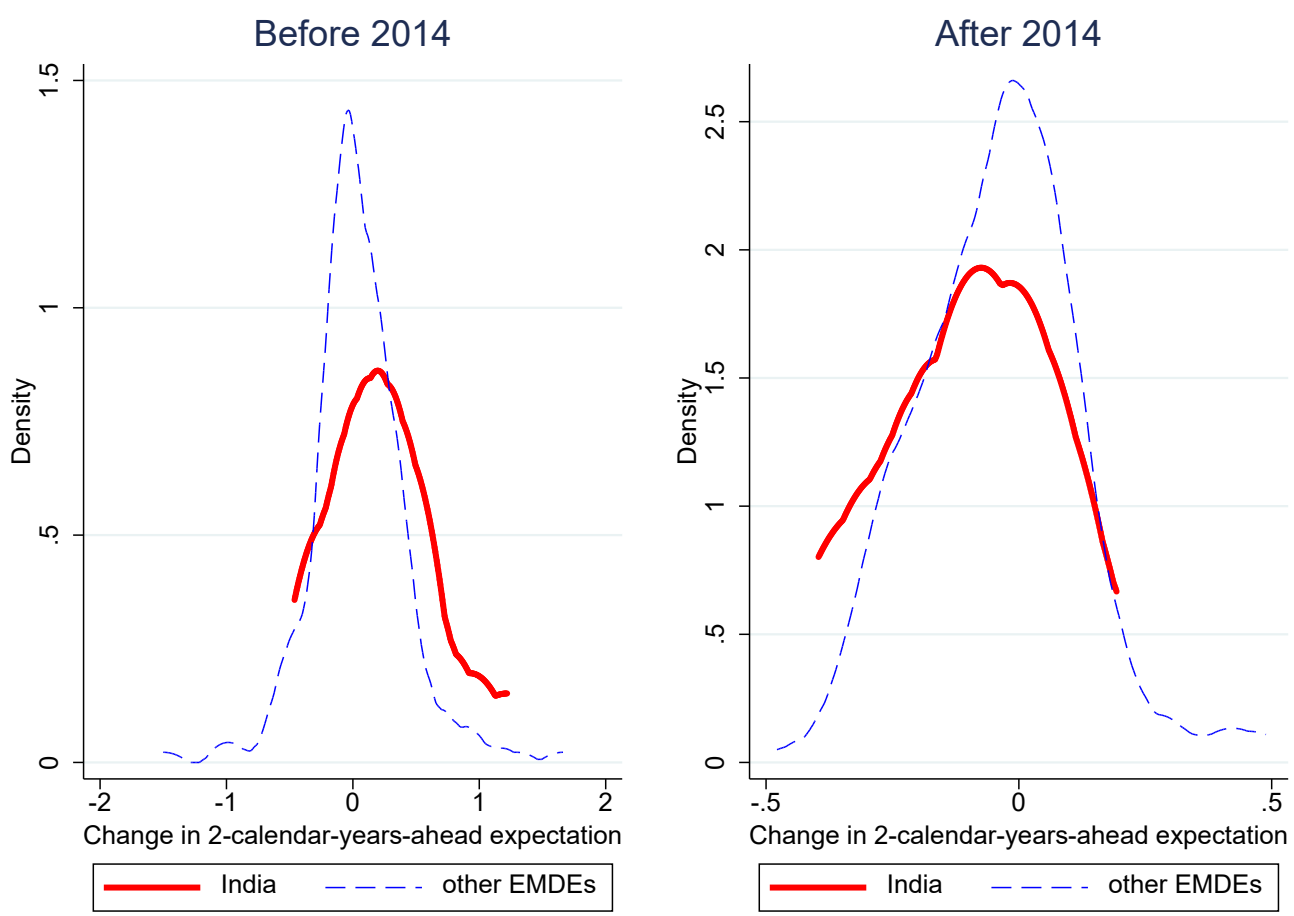

Sources: Consensus Forecast database; and Authors' calculations

Note: "after 2014" includes 2014. 
Figure A.2 Distribution of Revisions in Two-Year Ahead Inflation Expectations: India vs. Other Emerging Markets, Split the Sample in 2016
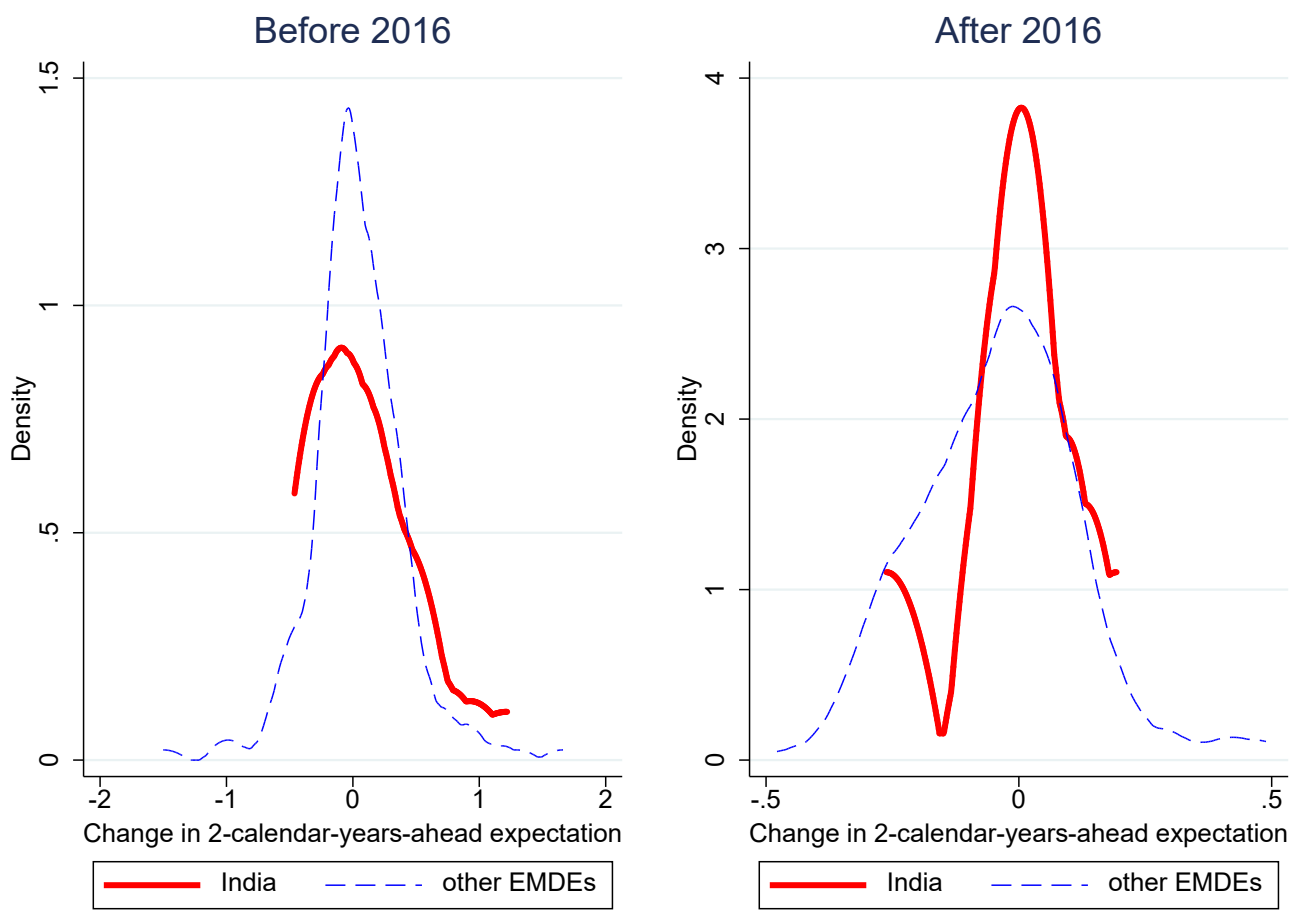

Sources: Consensus Forecast database; and Authors' calculations Note: "after 2016" includes 2016. 
Figure A.3 Correlation Between Revisions in Inflation Forecasts for Current Year and Two-Years Ahead: Split the Sample at 2014
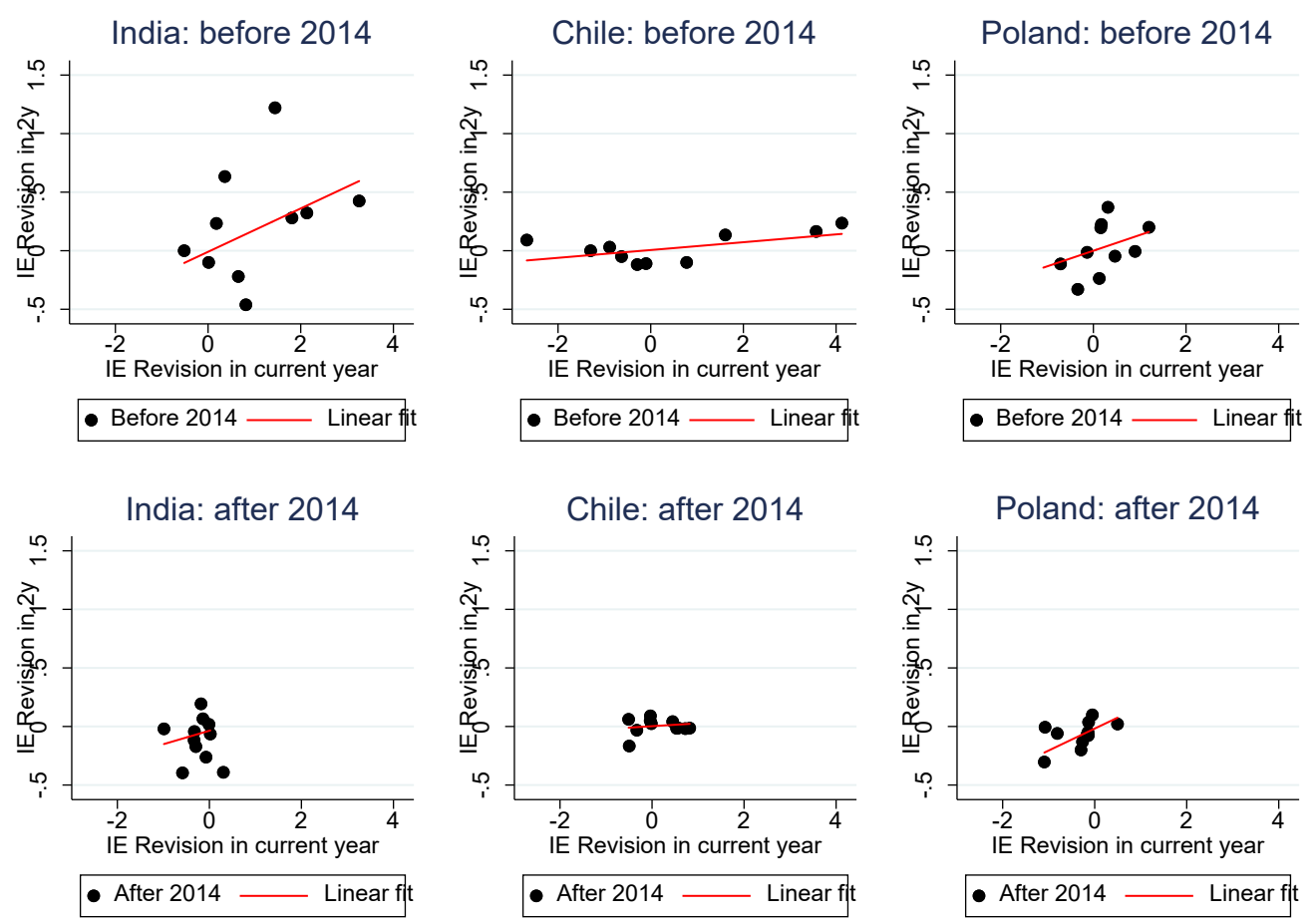

Sources: Consensus Forecast database; and Authors' calculations Note: "after 2014" includes 2014. 
Figure A.4 Correlation Between Revisions in Inflation Forecasts for Current Year and Two-Years Ahead: Split the Sample at 2016
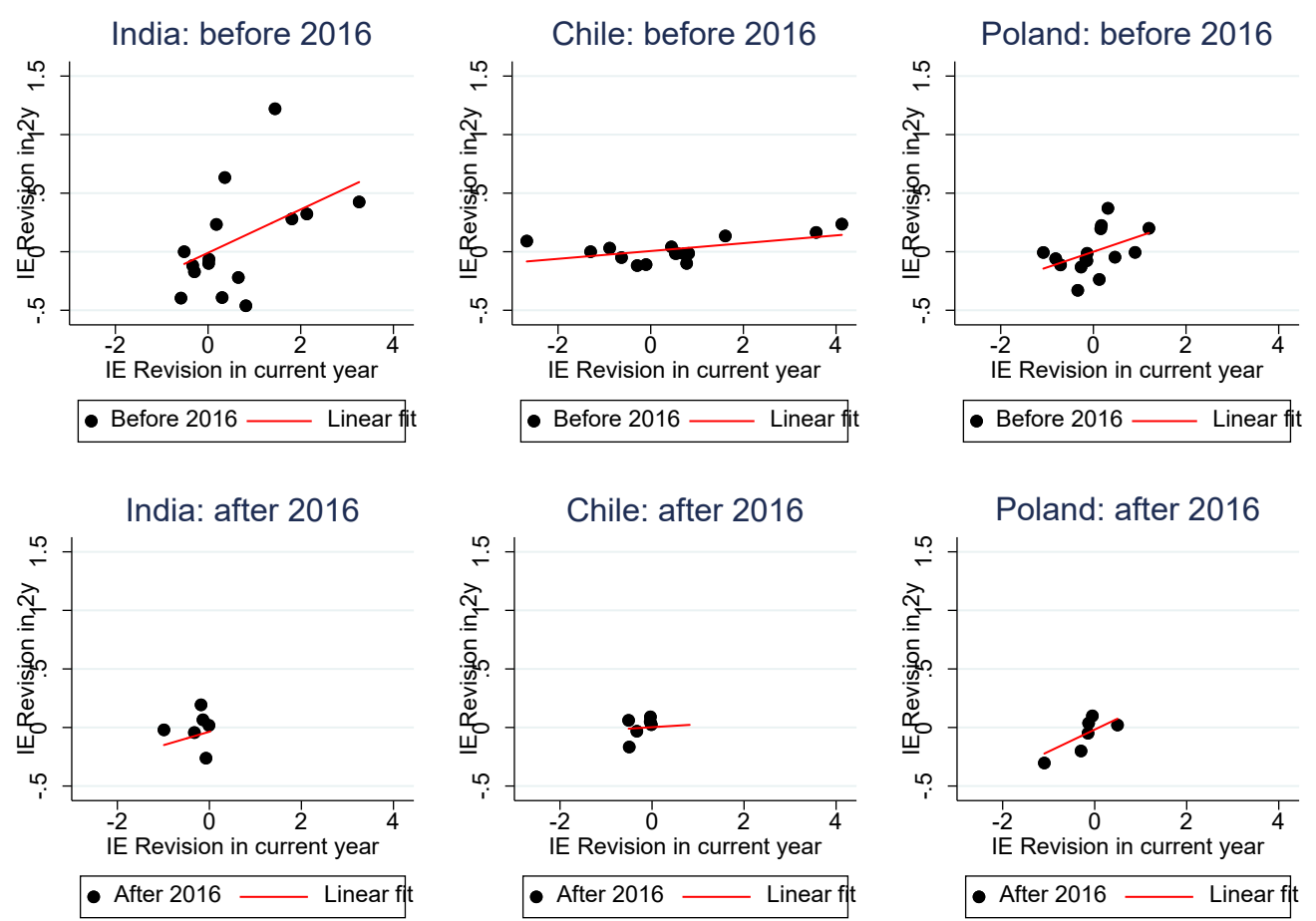

Sources: Consensus Forecast database; and Authors' calculations Note: "after 2016" includes 2016. 


\section{REFERENCES}

Anand, R., D. Ding, and V. Tulin, (2014), "Food Inflation in India: The Role for Monetary Policy," IMF Working Paper 14/178.

Behera, H., G. Wahi, M. Kapur, (2018), "Phillips curve relationship in an emerging economy: Evidence from India,” Economic Analysis and Policy, Vol 59, Sept, pp 116-126.

Bems, R., F. Caselli, F. Grigoli, B. Gruss, and W. Lian, (2018a), "Expectations Anchoring and Inflation Persistence," IMF Working Paper 18/280.

Bems, R., F. Caselli, F. Grigoli, B. Gruss, and W. Lian, (2018b), "Is Inflation Domestic or Global? Evidence from Emerging Markets,” IMF Working Paper 18/241.

Benes, J., K. Clinton, A. George, P. Gupta, J. Joice, O. Kamenik, D. Laxton, P. Mitra, G. V. Nadhanael, R. Portillo, W Hou, and F. Zhang, (2017), "Quarterly Projection Model for India: Key Elements and Properties,” IMF Working Paper 17/33.

Cecchetti, S., and R. Moessner, (2008), "Commodity prices and inflation dynamics," BIS Quarterly Review, December.

Chinoy, S., (2019), "Parsing India's inflation dynamics," JP Morgan Chase Bank Economic Research Note, April 12.

De Mendonca, H. F., and G.J. de Guimaraes e Souza, (2012), "Is inflation targeting a good remedy to control inflation?" Journal of Development Economics, 98, 178-91.

Dholakia, R. H., and Kadiyala, V. S., (2018) "Changing Dynamics of Inflation in India," Economic \& Political Weekly, Vol 53, Issue 9, March $3^{\text {rd }}$.

Gali, J., and M. Gertler, (1999),"Inflation dynamics: A structural econometric analysis," Journal of Monetary Economics, 44, no. 2: 195-222.

Eichengreen, B., P. Gupta, R. Choudhary, (2020) "Inflation Targeting in India: An Interim Assessment" draft manuscript, 25 September.

Gerlach, S., and P. Tillmann, (2012), "Inflation targeting and inflation persistence in AsiaPacific," Journal of Asian Economics, 23, 4: 360-373.

Goncalves, C.E., and J.M. Salles, (2008), "Inflation targeting in emerging economies: what do the data say?” Journal of Development Economics, 85, 312-18.

IMF, (2018), "Regional Economic Outlook: Asia Pacific, Chapter 2 - Low Inflation in Asia: How Long Will it Last?" May. 
Lin, S. and H. Ye, (2009), "Does inflation targeting make a difference in developing countries?" Journal of Development Economics, 89, 118-23.

Patra, M., J.K. Khundrakpam, and J. Joice, (2018), "Non-Linear, Asymmetric and TimeVarying Exchange Rate Pass-Through: Recent Evidence from India," Reserve Bank of India Working Paper Series WPS 02/2018.

Pattanaik, S., S. Muduli, and S. Ray, (2019), "Inflation Expectations of Households: Do They Influence Wage-Price Dynamics in India?" Reserve Bank of India Working Paper Series, WPS $01 / 2019$.

Raj, J., Misra, S., George, A.T., and John, J. (2020) "Inflation Measures in India - An Empirical Evaluation using CPI Data", RBI Working Paper No. 05/2020

Samarina, A., M. Terpstra, and J De Haan, (2014), "Inflation targeting and inflation performance: a comparative analysis," Applied Economics Vol 46, Issue 1.

Sonna, T., H. Joshi, A. Sebastian, and U. Sharma, (2014), "Analytics of Food Inflation in India," RBI Working Paper Series 10/2014. 